\title{
Large fluctuations but constant mean temperatures allow corals to persist in intertidal rock pools on the east coast of South Africa
}

\author{
Kaylee Smit ${ }^{1,2^{*}}$ (iD and David Glassom ${ }^{1}$
}

\begin{abstract}
Intertidal corals have been under-studied yet they provide scope for understanding adaptation and acclimatisation of corals to marginal conditions. Corals in intertidal rock pools along the east coast of South Africa withstand large temperature fluctuations, and marginal conditions for survival and growth. Four sites along the KwaZulu-Natal (KZN) coastline were sampled to determine latitudinal differences in coral communities, from $27^{\circ} \mathrm{S}$ to $31^{\circ} \mathrm{S}$. Water temperature of rock pools at each site was monitored to see if temperature determined coral diversity in intertidal pools. Sixteen coral species were present in rock pools overall. Each of three sites in northern and central KZN hosted 12 coral taxa whereas only six taxa occurred at the most southern site. Anomastrea irregularis was the most abundant species at all sites, followed by Pocillopora verrucosa and P. damicornis. Unexpectedly, rock pool temperatures did not show a trend with latitude and thus cannot explain this decline in coral diversity. Temperatures in isolated rock pools showed large summer day time fluctuations of more than $10^{\circ} \mathrm{C}$ at spring tide. However, temperatures drop substantially at high tide, lowering the mean rock pool temperature and possibly allowing these coral communities to persist in the marginal conditions of rock pools in South Africa.
\end{abstract}

Keywords: Intertidal, Temperature, Rock pools, Hard coral, Pocillopora verrucosa, Anomastrea irregularis

\section{Background}

'Marginal' environments are characterised by sub-optimal, fluctuating conditions [1]. For corals, this definition can be refined to refer to habitats that occur near or beyond the limits of natural coral distribution, based on physical factors including light, temperature and salinity [2]. The intertidal zone is a highly dynamic, benthic environment, imposing a variety of physical stresses on biota, including possible periodic aerial exposure, fluctuations in temperature and salinity, high solar radiation and strong wave action and sedimentation, over short periods $[3,4]$. Intertidal environments are thus marginal coral habitats and corals occurring there must tolerate harsh environmental conditions $[3,5]$. Nonetheless, rich coral communities occur in intertidal reef habitats despite

\footnotetext{
*Correspondence: kayles.smit@gmail.com

${ }^{1}$ School of Life Science, University of KwaZulu-Natal, Westville Campus, Private Bag X54001, Durban 4000, South Africa

Full list of author information is available at the end of the article
}

the harsh conditions [4] and may be used as models to understand resilience, including to climate change, in coral assemblages $[4,6]$. Reef environments considered marginal today may become important under future climate conditions according to models [7], although intertidal habitats were not specifically included in the model.

Intertidal rocky shores of KwaZulu-Natal (henceforth KZN), on the east coast of South Africa (Fig. 1) are inhabited by a variety of scleractinian coral species. Although corals in the intertidal zone have been documented at several locations [e.g. 7-9], few studies have surveyed intertidal zones at high latitudes such as this. Little research has been conducted on the diversity or distributions of intertidal corals in the region, but corals have been observed as far south as Munster, at latitude $31^{\circ} 04^{\prime} \mathrm{S}$. Coral abundance was generally low in KZN rock pools, with some species represented by only one or two colonies, exceptions being Anomastrea irregularis, Pocillopora verrucosa and P. damicornis [10]. The only other published literature on these coral populations in South 


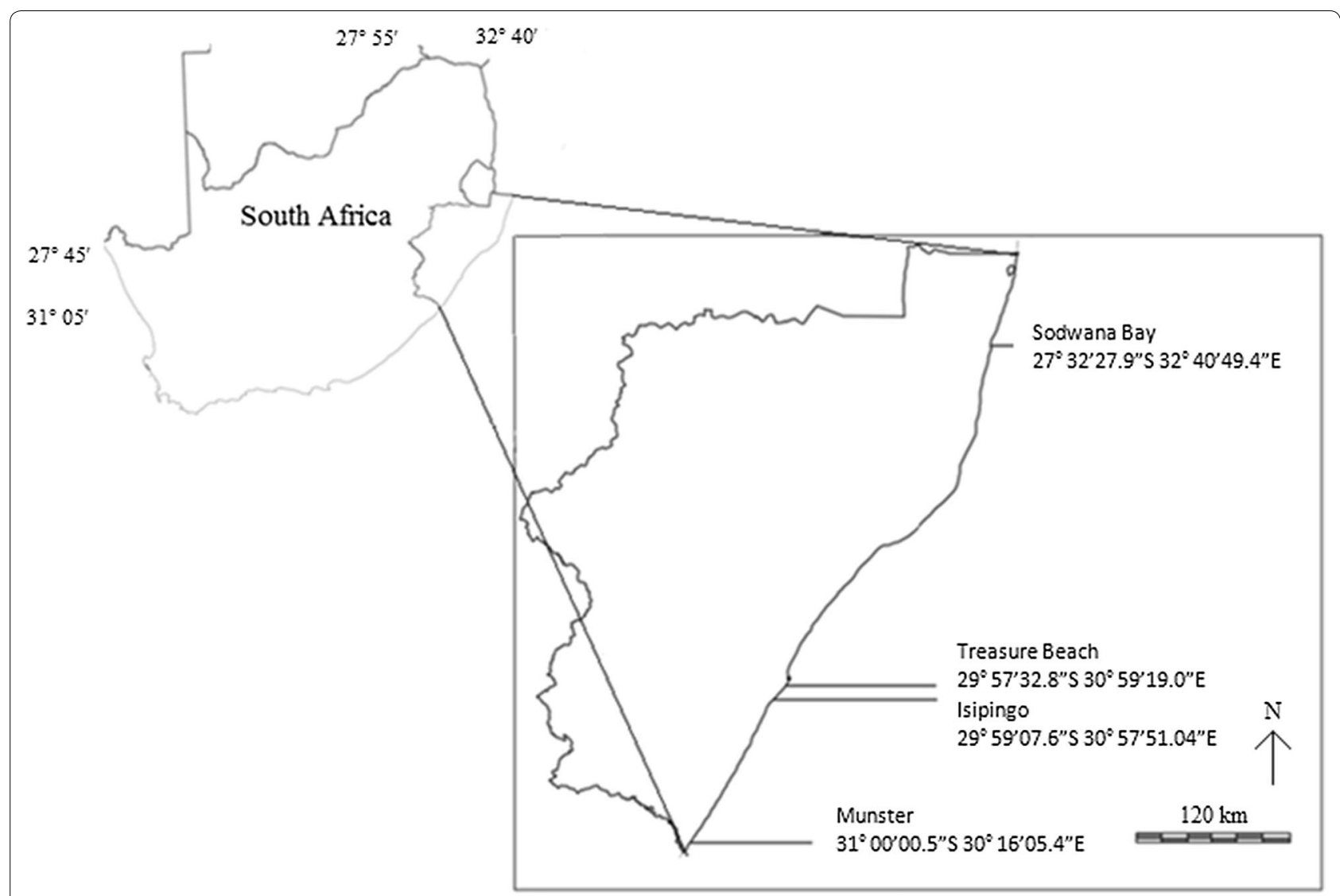

Fig. 1 Map of KZN showing the four study sites: Sodwana Bay in the north, Treasure Beach and Isipingo, and Munster in the south

Africa is the genetic connectivity of Acropora tenuis along KZN [11], and the sexual reproduction of Pocillopora damicornis in rock pools [12].

Temperature is considered a major constraint on coral distribution, with corals restricted to relatively narrow thermal ranges. Coastal summer sea surface temperatures (SSTs) in northern $\mathrm{KZN}$, measured by underwater temperature recorders, ranged from 27 to $29^{\circ} \mathrm{C}$ between 1993 and 2006 [13], while mean summer temperatures on the south coast ranged from 20.5 to $22.4{ }^{\circ} \mathrm{C}$ [14]. Coastal winter temperatures vary from $22.2^{\circ} \mathrm{C}$ on the north coast to $19.4{ }^{\circ} \mathrm{C}$ on the south coast [14]. A considerable temperature gradient is thus evident along the coast, particularly in summer.

The highest diversity of scleractinian corals is observed at low latitudes, where sustained warming of sea surface temperatures is often the main cause of coral mortality on subtidal reefs [15-17]. Low temperatures for sustained periods can however also affect coral survival [18]. This can be particularly significant for corals in temperate regions. For example, an extreme weather event resulted in a significant loss of coral diversity and abundance in the Hervey Bay, Australia [19]. Similar extreme weather and climatic events have also resulted in a loss of coral diversity or abundance [19], but this is usually over a prolonged period.

Tolerance to thermal stress is imperative for corals [20], and those taxa already found in marginal habitats for coral growth and survival may be less susceptible to future changes in climate and local environmental conditions $[1,18]$. Temperature patterns, sea surface temperature regimes and the response of corals are extensively studied globally, yet with focus on subtidal reef habitats [e.g. 5, 9, 16]. The occurrence and distribution of intertidal scleractinian coral species is however poorly documented particularly at high latitudes, let alone the local temperature patterns within these habitats. This information should provide a better understanding of the tolerance and resilience of scleractinian corals to thermal stress and help to predict the state of future coral assemblages in an era of global climate change.

Based on local sea surface temperate data collected from the east coast of South Africa, it is predicted that similar seasonal and latitudinal patterns would be expected in the intertidal zone; however no in situ 
temperature data has been recorded from rocky shores on the South African coastline to date.

We therefore surveyed the hard corals in rock pools along length of the KZN coastline to determine the diversity of species in pools at each site. We measured temperature variation in pools at each site for a year to determine whether differences in temperature could explain changes in coral diversity among sites. We hypothesised that lower temperatures would restrict the southerly distribution of corals in rock pools.

\section{Methods}

\section{Study site}

This study was conducted on the east coast of South Africa, in the KwaZulu-Natal (KZN) province (Fig. 1). The South African coastline experiences a semi-diurnal tidal cycle with a range varying from 1.5 to $2.23 \mathrm{~m}$. Intertidal rocky shores are thus exposed for approximately $4 \mathrm{~h}$ twice a day during spring tides. Inshore habitats in KZN are divided between two bioregions, the Delagoa region in the north and the Natal bioregion in the rest of the province, with the break at Cape Vidal, south of Sodwana Bay [21], although this categorisation may not apply to all faunal groups [14]. Four sites were chosen along the length of KZN (Fig. 1). The northern-most and only site within the Delagoa bioregion (Fig. 1) was Jesser point at Sodwana Bay $\left(27^{\circ} 3^{\prime} 27.9^{\prime \prime} \mathrm{S} 32^{\circ} 40^{\prime} 49.4^{\prime \prime} \mathrm{E}\right)$. Two sites, Treasure Beach and Isipingo, in the centre of the province and a southern site at Munster $\left(31^{\circ} 00^{\prime} 00.5^{\prime \prime} \mathrm{S} 30^{\circ} 16^{\prime} 05.4^{\prime \prime} \mathrm{E}\right)$ all occur in the Natal bioregion. Sodwana Bay is classified as a wavecut rocky platform while the other sites are classified as exposed rocky headlands [22]. Wave cut rocky platforms are horizontally-orientated rock surfaces, created by the erosion by waves along a relatively high energy coastline, while exposed rocky headlands are more verticallyoriented rock surfaces, an extension from the land [22]. Despite these differences, the rock pools at each of our study sites occurred at near-horizontal surfaces between the high- and low-tide marks.

\section{Sampling}

The number of rock pools sampled varied per site, as the aim was to survey the coral community at each site as thoroughly as possible and all rock pools within a demarcated site were surveyed. The sampling area at each site was demarcated to approximately $150 \mathrm{~m}$ in length and $30 \mathrm{~m}$ in width. At least one colony of every coral species present was photographed using a Nikon underwater camera or a GoPro Hero $3^{\circledR}$. Corals were identified to species level or to the highest resolution possible.

At three of the four sites, one rock pool was selected for water temperature measurement. Rock pools of similar size and depth were chosen, but it was impossible to avoid some variation among sites, particularly in the case of Munster where pools were smaller than at the other sites (Table 1). Nevertheless this is suitable to determine a general temperature pattern in isolated rock pools at different latitudinal positions, which is not documented along the east coast of South Africa.

Temperature data were collected using small data loggers, (iButtons Maxim $^{\circledR}$, San Jose, CA, US), cross calibrated in the laboratory with an accuracy of $\pm 0.2{ }^{\circ} \mathrm{C}$. Individual iButtons were sealed in a waterproof silicon casing and attached to the rocky substrate, out of sight of casual visitors, using waterproof epoxy putty, Aquamend ${ }^{\mathrm{TM}}$. Two iButtons were attached at depths of $20-30 \mathrm{~cm}$ in each pool. Physical descriptions of each pool were measured (Table 2), and iButtons were never exposed to the air at spring low tide. Loggers were set to record temperatures every $30 \mathrm{~min}$ and were replaced every $4-6$ weeks, for 1 year. Some iButtons were however lost in the field, and data were not retrieved for these periods, resulting in some missing seasonal data. In particular, no data were collected in summer at Sodwana Bay. Daily temperature ranges were plotted for each season at each site.

Data were analysed using IBM SPSS vol. 21 and Graphpad Prism vol. 5. The temperature data were not normally distributed despite log and square root transformations, thus a non-parametric one-way repeated measures Analysis of Variance (ANOVA) was used to compare mean temperature among sites. A Friedman test was used to assess differences in seasonal temperature ranges among sites in autumn and winter. Where significant differences were found a Wilcoxon signed-rank test was used to compare significant differences for all site combinations. A Wilcoxon signed-rank test was also used to compare summer temperature data between Munster and Isipingo, the only two sites where summer temperature is available.

\section{Results}

Eight scleractinian coral families occurred in the intertidal zone along the KZN coast with a total of 16 species (Table 2). Merulinidae have the highest representation

\begin{tabular}{|c|c|c|c|c|}
\hline & Munster & Isipingo & Treasure Beach & Sodwana Bay \\
\hline Length (m) & 1.50 & 1.70 & 1.60 & 1.30 \\
\hline Width (m) & 0.90 & 0.90 & 1.00 & 1.00 \\
\hline $\begin{array}{l}\text { Surface area } \\
\left(\mathrm{m}^{2}\right)\end{array}$ & 1.40 & 1.53 & 1.60 & 1.30 \\
\hline Depth (m) & 0.20 & 0.50 & 0.40 & 0.80 \\
\hline $\begin{array}{l}\text { Estimated } \\
\quad \text { volume }\left(\mathrm{m}^{3}\right)\end{array}$ & 0.37 & 0.77 & 0.64 & 1.04 \\
\hline
\end{tabular}

Temperature data were collected from 1 rock pool per site 
Table 2 Biodiversity of scleractinian corals in the intertidal rock pools of KwaZulu-Natal, at four sites

\begin{tabular}{|c|c|c|c|c|c|c|}
\hline Family & Genus & Species & Sodwana Bay & Treasure Beach & Isipingo & Munster \\
\hline \multirow[t]{3}{*}{ Pocilloporidae } & Pocillopora & verrucosa & * & * & * & * \\
\hline & & damicornis & * & * & * & \\
\hline & Stylophora & pistillata & & * & & * \\
\hline \multirow[t]{2}{*}{ Acroporidae } & Acropora & (a) & * & * & * & \\
\hline & & (b) & & * & * & \\
\hline Siderastreidae & Anomastrea & irregularis & * & $*$ & * & * \\
\hline Agariciidae & Pavona & venosa & * & * & * & \\
\hline \multirow[t]{3}{*}{ Mussidae } & Acanthastrea & echinata & * & * & * & * \\
\hline & Blastomussa & merleti & & & $*$ & \\
\hline & Unidentified & & * & * & & \\
\hline \multirow[t]{5}{*}{ Merulinidae } & Hydnophora & exesa & * & * & $*$ & \\
\hline & Favia & malthaii/pallida & & & * & \\
\hline & & speciosa & * & & & * \\
\hline & Favites & pentagona & * & * & * & * \\
\hline & Goniastrea & (d) & * & & & \\
\hline Poritidae & Porites & (e) & * & * & * & \\
\hline
\end{tabular}

Species is unknown for those marked (a-e)

* Represents at least one observation of that group

of coral genera and species, followed by Pocilloporidae and Mussidae. High coral diversity occurs in the northern and central parts of the province, with Isipingo and Treasure Beach hosting an equal number of families and genera to Sodwana Bay (Table 2). A lower coral diversity is then suddenly observed at Munster. However, six coral species from four families are still present there (Table 2).

Temperature fluctuations at Munster and Isipingo are larger in summer than in winter (Figs. 2, 3). Maximum temperature fluctuations occur at spring tides when isolation of pools from the sea is longest, and when pools are isolated and exposed to the sun accentuating temperature differences between day and night. During summer, temperatures at Munster and Isipingo may experience a $10{ }^{\circ} \mathrm{C}$ change over one tidal cycle (Fig. 2). The lowest and highest recorded temperatures were 19.5 and $32.5{ }^{\circ} \mathrm{C}$ respectively (Table 3 ). Conversely, winter temperatures change by only $2-4.5^{\circ} \mathrm{C}$ throughout one tidal cycle (Fig. 2). Temperature variation differs significantly between seasons, taking into account all sites $\left[\mathrm{X}^{2}(2)=8.300, \mathrm{P}=0.021\right]$. Post hoc tests showed that summer (at Munster and Isipingo) had the highest temperature range $(Z=-1.0832993$, $\mathrm{P}=0.008)$, with temperature variation in autumn significantly higher than winter $(\mathrm{Z}=-0.0542993, \mathrm{P}=0.030)$.

There was also a significant difference in temperature between sites during autumn and winter $\left[\mathrm{x}^{2}(2)=6.211, \mathrm{P}=0.021\right]$, with Munster experiencing larger temperature fluctuations than at Isipingo

Table 3 The seasonal mean, minimum, maximum and range of rock pool temperatures at each site along the South African coast

\begin{tabular}{|c|c|c|c|c|c|c|}
\hline \multirow[t]{2}{*}{ Site } & \multirow[t]{2}{*}{ Season } & \multicolumn{5}{|c|}{ Water temperature $\left({ }^{\circ} \mathrm{C}\right)$} \\
\hline & & Mean & SD & Min & Max & Range \\
\hline \multirow[t]{2}{*}{ Sodwana Bay } & Autumn & 23.06 & 0.97 & 16.50 & 26.50 & 10.00 \\
\hline & Winter & 21.72 & 1.07 & 17.50 & 25.00 & 7.50 \\
\hline \multirow[t]{3}{*}{ Isipingo } & Summer & 24.68 & 1.88 & 21.50 & 32.00 & 10.50 \\
\hline & Autumn & 22.15 & 0.99 & 20.50 & 26.50 & 6.00 \\
\hline & Winter & 21.16 & 2.20 & 17.50 & 24.00 & 6.50 \\
\hline \multirow[t]{3}{*}{ Munster } & Summer & 23.40 & 1.98 & 19.50 & 32.50 & 13.00 \\
\hline & Autumn & 21.91 & 1.48 & 17.00 & 30.00 & 13.00 \\
\hline & Winter & 22.02 & 0.74 & 18.50 & 26.00 & 7.50 \\
\hline
\end{tabular}




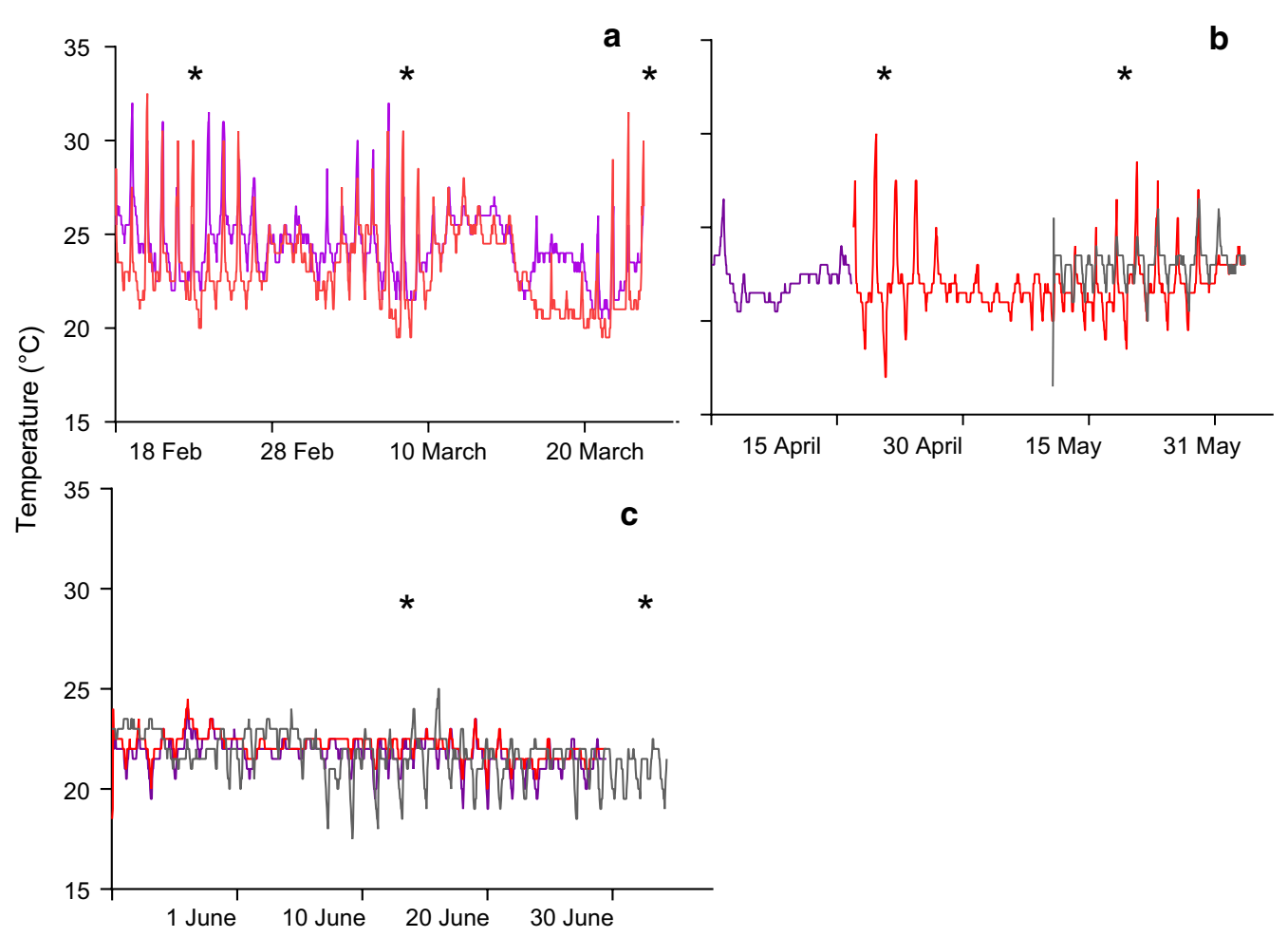

Fig. 2 Daily temperature range in the intertidal rock pools of KwaZulu-Natal in 2013, during summer (a), autumn (b) and winter (c) at Munster (red), Isipingo (purple) and Sodwana Bay (gray). Temperatures were logged every $30 \mathrm{~min}$. Not all sites are represented. Stars represent spring tides

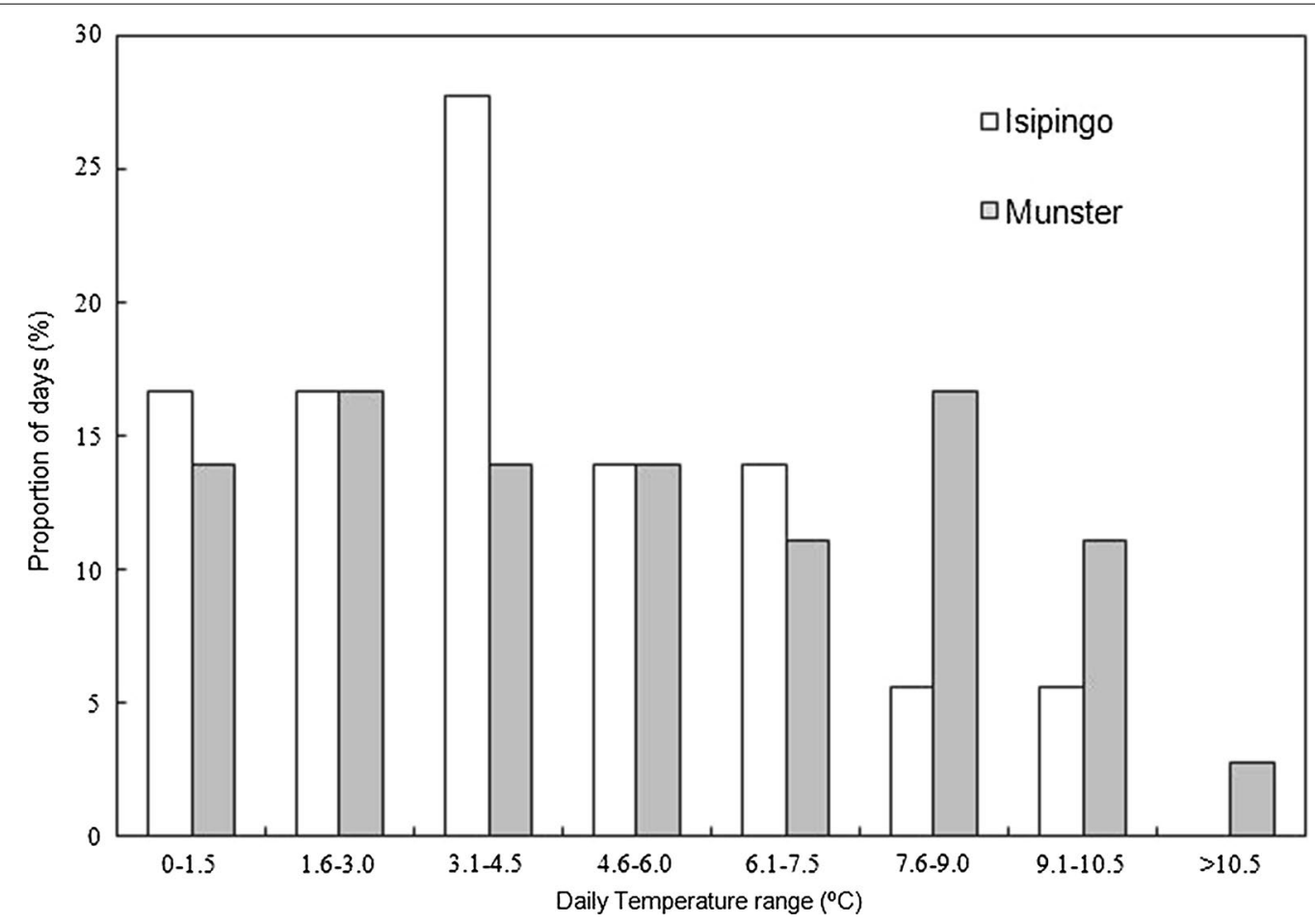

Fig. 3 The percentage occurrence of daily temperature ranges during summer at Munster and Isipingo 
$(\mathrm{Z}=-1.343, \mathrm{P}=0.005)$. Munster experiences the largest change in temperature in April, with a minimum and maximum temperature of 17 and $30{ }^{\circ} \mathrm{C}$ respectively (Fig. 2, Table 3). In winter, temperatures range from 17.5 to $26^{\circ} \mathrm{C}$ across all sites (Table 3). Maximum temperatures at Munster are also higher than all other sites in autumn and winter (Table 3).

Mean temperature differed significantly among sites only during autumn and winter [autumn: $\chi^{2}(2)=6.118$, $\mathrm{P}=0.027$; winter: $\left.\mathrm{H}=\chi^{2}(2)=2.699, \mathrm{P}=0.0\right]$. However, differences were often less than $1{ }^{\circ} \mathrm{C}$ among all the sites. Mean summer temperatures at Munster and Isipingo were 23.40 and $24.68{ }^{\circ} \mathrm{C}$ respectively (Table 3 ). Mean winter temperatures at each site were $22.02{ }^{\circ} \mathrm{C}$ at Munster, $21.16^{\circ} \mathrm{C}$ at Isipingo and $21.72{ }^{\circ} \mathrm{C}$ at Sodwana Bay (Table 3).

\section{Discussion}

A total of sixteen coral species occurred in pools along the coast. Rock pools in central KZN host as many coral species as the rock pools in Sodwana Bay, a more tropical environment (Table 2). Twelve species from seven families were present in pools at each of these locations, however coral diversity declines sharply at Munster with only six hard coral species present from four families (Table 2). These families included Pocilloporidae, Siderastreidae, Mussidae and Merulinidae. Pocillopora was the most abundant genus along the entire coastline, confirming previous observations [10] and attesting to the persistence of the population. Additionally, this study found very high abundances of A. irregularis at all sites, with up to 400 individuals at Isipingo (K. Smit, unpublished data).

Species occurring at the southernmost site in this study have also been surveyed at other high latitude reefs, despite the lack of surveys in similar intertidal habitats. The genera Pocillopora and Stylophora are common at high latitudes $[19,20,23]$. Corals of these genera are widespread, hardy and abundant in most reef habitats [24], often being referred to as 'weedy' or 'tramp' species. However, they are not regarded as being particularly resilient to thermal stress [25, 26]. Anomastrea irregualris, to our knowledge, has only been previously reported at a high latitude reef in the Arabian Gulf [23], but since its distribution is limited to the Western Indian Ocean region and the Gulf [24], there are limited possible locations for its occurrence. Favia speciosa, Favites pentagona, and Acanthastrea echinata are all common species in a wide range of habitats and have been recorded at multiple high latitude reefs in Japan, Australia, the Arabian and Persian Gulf [19, 20, 23, 27].

Faviids are more tolerant to marginal high latitude habitats and are generally resistant to stress [28, 29]. In contrast, Acropora or Porites tend to dominate at lower latitudes. Furthermore, Mizerek et al. [30] suggest that tabular, encrusting and massive species, and those with similar traits, are more likely to persist "beyond reef" habitats or latitudes. Aside from the Pocilloporidae, all other taxa observed in this study exhibit massive or encrusting growth forms. Thus all the species observed at the southern limit of our study are either hardy, common corals or are known to be opportunistic in a variety of reef habitats. Species assemblages of several exposed intertidal habitats in South Africa differ between the tropical Delagoa bioregion, in which Sodwana bay falls and the subtropical Natal bioregion where the other three sites are situated [21]. These include the fauna of exposed intertidal habitats [21] fish [31] and subtidal reef corals $[13,32]$ which all decline southwards along the KZN coast. We therefore expected a similar decline in coral species diversity and colony abundance in the intertidal zone. However, intertidal coral diversity is maintained into the central parts of $\mathrm{KZN}$, across the boundary of the two bioregions.

The number of hard coral species observed in pools at the central sites in this study was comparable to the number on Aliwal Shoal, a nearby subtidal reef [33], further suggesting that conditions in intertidal pools at these sites were not the major constraint on species diversity. Although far more species have been observed in intertidal habitats of reef flats [4], the isolated pools of subtropical intertidal shores in this study provide a far more restricted habitat and a less species rich assemblage was expected.

In part, the high diversity of species observed in the central parts of the province may be due to the similarity of water temperatures in rock pools along the coast. Although statistically significant the mean temperature difference among sites, was less than $1{ }^{\circ} \mathrm{C}$ during autumn and winter and during summer at Munster and Isipingo. This contrasts with the sub-littoral sea surface temperature, which declines southward along the coast [14]. There were nevertheless considerable differences in temperature ranges among sites, which may be attributed to the properties of individual pools. Although no data were collected in summer for Sodwana Bay, the absence of significant temperature differences between this and other sites in the remaining seasons implies that the absence of a gradient would extend to Sodwana Bay in summer.

Rock pool temperatures at Munster, the southernmost site, remain high and experienced some of the largest temperature fluctuations (Fig. 2). The pool at this site had the lowest volume of all the pools in which temperature was measured (Table 1), making it susceptible to large temperature variations, especially during summer days. If the pools at this site were generally smaller than at other sites, the increased temperature range could 
partially explain the decline in species diversity at this site and the occurrence only of hardy or weedy coral species. Larger pools with a larger volume of water have a higher heat capacity, thus it requires more energy to heat the water temperature. Thus, the lower heat capacity of smaller and/or shallower rock pools creates more heating and higher temperatures during exposure at low tide, and also greater and faster heat loss as the tide comes in. Further cooling as the tide comes in lowers rock pool mean temperatures, likely allowing these corals to acclimatise to such temperature cycles. Corals in these pools did not suffer aerial exposure at low tide, as has been observed elsewhere [4], possibly facilitating their resilience in these pools.

The water temperature of intertidal rock pools in KZN undergoes large diel fluctuations over short periods (Figs. 2, 3). In summer and during daytime spring low tides, when pools are isolated and exposed to the sun for roughly $5 \mathrm{~h}$, temperatures can fluctuate more than ten degrees over as little as $2 \mathrm{~h}$. Large temperature fluctuations are common for corals inhabiting shallow-water environments, however we did not find studies that have reported daily temperature ranges as high as this study [e.g. 8, 34, 35]. Summer diel temperature fluctuations of 5-6 and $8.2{ }^{\circ} \mathrm{C}$ occurred in reef flats near Java and in the Gulf of Oman respectively [34, 35], while temperatures in isolated pools of different sizes in American Samoa fluctuated by no more than $6.9^{\circ} \mathrm{C}$ over the tidal cycle [8]. Java and Samoa are more tropical than those of this study yet maximum rock pool temperatures in this study are comparable $[8,36]$. Thus it appears that rock pools at higher latitudes in temperate environments tend to cool down to lower temperatures, especially at night, therefore increasing the daily range, as shown by this study.

Although, sustained low mean temperatures, specifically less than $18{ }^{\circ} \mathrm{C}$, can also have a detrimental effect on the survival of hard corals, particularly in subtropical or temperate climates [18, 19]. Results from this study showed that temperature fluctuations in isolated rock pools would be considered extreme for subtidal coral reefs. Large colonies of $P$. verrucosa were observed throughout the study, with an average length of $15 \mathrm{~cm}$, some reaching up to $28 \mathrm{~cm}$ in length (K. Smit, personal observation, unpublished data). Large colonies of $A$. irregularis were also observed, among other individuals of massive coral taxa. Thus temperature patterns over the past few years were unlikely to have affected the mortality of rock pool corals.

Extreme weather and sea temperatures [18, 19, 37] may cause the mortality of local coral populations. Along the coastline of KZN, temperatures measured in rock pools were neither variable, high nor low enough to prevent corals persisting. Although this was a short term study and may not encompass the full range of temperatures in these rock pools, our results showing resilience of intertidal corals to high and variable temperatures are supported by the survival of intertidal corals after the 1997/1998 El Nino [8, 37]. Taxa which persist in these pools may be more suited to survival under future climate change scenarios, and may provide an indication of the type of community assemblages expected as global warming continues.

Aside from temperature, a major determinant of coral distribution is the amount of light available, with winter irradiance in particular constraining the latitudinal and depth ranges of some coral species [38]. Although figures for winter irradiance along the coast of KwaZuluNatal are not available, mean annual irradiance declines from $1768 \mathrm{kWh} / \mathrm{m}^{2}$ at Sodwana Bay to $1629 \mathrm{kWh} / \mathrm{m}^{2}$ at Munster (data from Geosun Africa). Irradiance thus may play a role in the lower coral species richness observed at Munster, although further measurements would be needed to confirm this. Some coral species may extend their ranges by supplementing autotrophic nutrition with heterotrophic feeding $[38,39]$. At least two of the coral species found at Munster, $A$. irregularis and $P$. verrucosa do so (K. Smit, unpublished data), however data are not available for the other species and we cannot ascribe their presence there to their modes of nutrition. Finally, other species-specific factors such as larval dispersal potential, which could limit the distribution of species along the coast, could not be accounted for in this study.

In summary, the hypothesis of this study is rejected. An array of hard corals persists in marginal intertidal rock pools along the coast of KwaZulu-Natal. The constant mean temperatures of rock pools suggest that temperature does not play an important role in determining the southern distribution limit of these species. The role of microhabitats in the intertidal zone has been emphasised [40-42]. The absence of a strong temperature gradient in rock pools along the coast and the relatively high water temperature in pools, especially at the southern extent of the study, potentially allow microhabitats where a diverse assemblage of hard corals can survive grow and reproduce. These conditions seem to favour some species, especially $P$. verrucosa and A. irregularis. Other factors, such as irradiation levels and species traits, including the degree to which species feed heterotrophically, may also influence their distributions. Understanding how these corals survive may help to understand general patterns of adaptation and acclimatisation of corals to thermal and other physical stresses.

\section{Abbreviations}

KZN: KwaZulu-Natal; SST: sea surface temperature; Fig: figure; UKZN: University of KwaZulu-Natal; NRF: National Research Foundation. 


\section{Authors' contributions}

KS was responsible for the study design, data collection, analysis and interpretation of the data and write-up of the manuscript. DG assisted with data collection and interpretation of the data and assisted with the writing. Both authors read and approved the final manuscript.

\section{Author details}

${ }^{1}$ School of Life Science, University of KwaZulu-Natal, Westville Campus, Private Bag X54001, Durban 4000, South Africa. ${ }^{2}$ Present Address: Oceanography Department, Nelson Mandela Metropolitan University, South Campus, Summerstrand, Port Elizabeth 6001, South Africa.

\section{Acknowledgements}

The authors would like to thank and acknowledge Sean Smit for assistance in the field, collecting temperature data. We are grateful for support from the University of KwaZulu-Natal (UKZN) and funding from UKZN, the National Research Foundation (NRF) and the Rufford Foundation. Comments from two anonymous reviewers greatly improved the quality of the manuscript.

\section{Competing interests}

The authors declare that they have no competing interests.

\section{Availability of data and materials}

The datasets during and/or analysed during the current study available from the corresponding author on reasonable request.

\section{Funding}

Funding for this project was provided by the University of KwaZulu-Natal (UKZN), the National Research Foundation (NRF) and the Rufford Foundation. No part was played by the funders in any aspect of the project other than funding support.

Received: 11 August 2016 Accepted: 20 January 2017 Published online: 08 February 2017

\section{References}

1. Perry CT, Larcombe P. Marginal and non-reef-building coral environments. Coral Reefs. 2003;22:427-32.

2. Kleypas JA, McManus JW, Meñez LB. Environmental limits to coral ree development: where do we draw the line? Am Zool. 1999;39:146-59.

3. Anthony KN, Kerswell AP. Coral mortality following extreme low tides and high solar radiation. Mar Biol. 2007;151:1623-31.

4. Richards ZT, Garcia RA, Wallace CC, Rosser NL, Muir PR. A diverse assemblage of reef corals thriving in a dynamic intertidal reef setting (Bonaparte archipelago, Kimberley, Australia). PLoS ONE. 2015;10:1-17.

5. Brown BE, Clarke KR, Warwick RM. Serial patterns of biodiversity change in corals across shallow reef flats in KO. Phuket, Thailand, due to the effects of local (sedimentation) and regional (climatic) perturbations. Mar Biol. 2002;141:21-9.

6. West JM, Salm RV. Resistance and resilience to coral bleaching: implications for coral reef conservation and management. Conserv Biol. 2003:17:956-67.

7. Brown BE, Holley MC. Coral assemblages of intertidal reef flats at Ko Phuket, Thailand. Phuket Mar Biol Cent Res Bull. 1984;30:1-10.

8. Craig P, Birkeland C, Belliveau S. High temperatures tolerated by a diverse assemblage of shallow-water corals in American Samoa. Coral Reefs. 2001;20:185-9.

9. Obura D. The diversity and biogeography of western indian ocean reefbuilding corals. PLOS ONE. 2011;7:1-13.

10. Crossland C. Reef corals of the South African coast. Ann Natal Mus. 1948;11:169-216.

11. Chiazzari B, Macdonald A, Schleyer M. High-latitude connectivity of the scleractinian coral Acropora tenuis in the south-western Indian Ocean, identified using nuclear intron and mitochondrial sequence data. Afr J Mar Sci. 2013:35:233-41.

12. Massé LM, Séré MG, Smit AJ, Schleyer MH. Sexual reproduction in Pocillopora damicornis at high latitude off South Africa. West Indian Ocean J Mar Sci. 2012;11:55-65.
13. Schleyer MH, Kruger A, Celliers L. Long-term community changes on a high-latitude coral reef in the Greater St Lucia Wetland Park, South Africa. Mar Pollut Bull. 2008;56:493-502.

14. Smit AJ, Roberts M, Anderson RJ, Dufois F, Dudley SJ, Bornman TG, Olbers J, Bolton JJ. A coastal seawater temperature dataset for biogeographical studies: large biases between in situ and remotely-sensed data sets around the coast of South Africa. PLoS ONE. 2013:8:1-13.

15. Jokiel P, Coles S. Response of Hawaiian and other Indo-Pacific reef corals to elevated temperature. Coral Reefs. 1990;8:155-62.

16. Coles SL, Brown BE. Coral bleaching: capacity for acclimatization and adaptation. Adv Mar Biol. 2003:46:183-223.

17. Goreau TJ, Hayes RL. Coral bleaching and ocean hotspots. Ambio. 1994;23:176-80.

18. Kemp DW, Oakley C, Thornhill DJ, Newcomb L, Schmidt GW, Fitt WK. Catastrophic mortality on inshore coral reefs of the Florida Keys due to severe low-temperature stress. Glob Change Biol. 2011;17:3468-77.

19. Butler IR, Sommer B, Zann M, Zhao JX, Pandolfi JM. The impacts of flooding on the high-latitude, terrigenoclastic influenced coral reefs of Hervey Bay, Queensland, Australia. Coral Reefs. 2013;32:1149-63.

20. Jahangir VS, Abolfazl S, Ali M, Shirvani A, Hasan S. Specific thermal regime and coral bleaching pattern in Hengam Island, the eastern Persian Gulf. J Persian Gulf. 2014:5:15-25.

21. Sink KJ, Branch GM, Harris JM. Biogeographic patterns in rocky intertidal communities in KwaZulu-Natal, South Africa. Afr J Mar Sci. 2005;27:81-96.

22. Jackson L, Lipschitz S. Coastal sensitivity atlas of southern Africa. In: Department of Transport, Cape Town; 1984.

23. McEwan T. Environmentally tough coral species as candidates for aquarium culture. Adv Coral Husb Public Aquar. 2008;2:185-9.

24. Veron J. Corals of the world, vol. 1. Queensland: Australian Institute of Marine Science; 2000

25. Guest J, Low J, Tun K, Wilson B, Ng C, Raingeard D, Ulstrup KE, Tanzil JI, Todd PA, Toh TC, McDougald D, Chou LM, Steinberg PD. Coral community response to bleaching on a highly disturbed reef. Sci Rep. 2016:6:20717.

26. Pisapia C, Burn D, Yoosuf R, Najeeb A, Anderson KD, Pratchett MS. Coral recovery in the central Maldives archipelago since the last major massbleaching, in 1998. Sci Rep. 2016;6:34720.

27. Thomson DP, Frisch AJ. Extraordinarily high coral cover on a nearshore, high-latitude reef in south-west Australia. Coral Reefs. 2010;29:923-7.

28. Hughes TP, Connell JH. Multiple stressors on coral reefs: a long term perspective. Limnol Oceanogr. 1999:44:932-40.

29. Bellwood DR, Hughes TP. Regional-scale assembly rules and biodiversity of coral reefs. Science 2001:292:1532-4.

30. Mizerek TL, Baird AH, Beaumont LJ, Madin JS. Environmental tolerance governs the presence of reef corals at latitudes beyond reef growth. Glob Ecol Biogeogr. 2016;25:979-87.

31. Turpie JK, Beckley LE, Katua SM. Biogeography and the selection of priority areas for conservation of South African coastal fishes. Biol Conserv. 2000;92:59-72.

32. Schleyer M. South African coral reef communities. Wetlands of South Africa. Department of Environmental Affairs. 1995;137-146.

33. Schleyer MH, Heikoop JM, Risk MJ. A benthic survey of Aliwal Shoal and assessment of the effects of a wood pulp effluent on the reef. Mar Pollut Bull. 2006:52:503-14.

34. Brown BE, Suharsono S. Damage and recovery of coral reefs affected by $E$ Nino related seawater warming in the Thousand Islands, Indonesia. Coral Reefs. 1990;8:163-70

35. Coles SL, Jokiel PL. Effects of temperature on photosynthesis and respiration in hermatypic corals. Mar Biol. 1977;43:209-16.

36. Oliver TA, Palumbi SR. Do fluctuating temperature environments elevate coral thermal tolerance? Coral Reefs. 2011·30:429-40.

37. Kelmo F, Bell JJ, Moraes SS, Gomes RT, Mariano-Neto E, Attrill MJ. Differential responses of emergent intertidal coral reef fauna to a large-scale El-Niño southern oscillation event: sponge and coral resilience. PLoS ONE 2014:9:1-10.

38. Muir PR, Wallace CC, Done T, Aguirre D. Limited scope for latitudinal extension of reef corals. Coral Reefs. 2015:348:1135-8.

39. Houlbrèque F, Ferrier-Pagès $C$. Heterotrophy in tropical scleractinian corals. Biol Rev. 2009:84:1-17

40. Helmuth B, Hofmann GE. Microhabitats, thermal heterogeneity, and patterns of physiological stress in the rocky intertidal zone. Biol Bull. 2001:201:374-84. 
41. Helmuth B, Harley CG, Halpin PM, O'Donnell M, Hofmann GE, Blanchette C. Climate change and latitudinal patterns of intertidal thermal stress. Science. 2002;298:1015-7.
42. Helmuth B, Mieszkowska N, Moore P, Hawkins SJ. Living on the edge of two worlds: changing the responses forecasting intertidal of rocky to climate ecosystems change. Annu Rev Ecol Syst. 2006;37:373-404.
Submit your next manuscript to BioMed Central and we will help you at every step:

- We accept pre-submission inquiries

- Our selector tool helps you to find the most relevant journal

- We provide round the clock customer support

- Convenient online submission

- Thorough peer review

- Inclusion in PubMed and all major indexing services

- Maximum visibility for your research

Submit your manuscript at www.biomedcentral com/submit
() Biomed Central 